\title{
Determinan Keberhasilan Penerapan Sistem Akuntansi Instansi Berbasis Akrual Dalam Penyusunan Laporan Keuangan Pemerintah
}

\author{
Muhajir Irfani ${ }^{1}$ \\ Fakultas Ekonomi dan Bisnis \\ Universitas Mataram, Indonesia \\ Email: imuhajir17@gmail.com
}

\author{
Endar Pituringsih ${ }^{2}$ \\ Fakultas Ekonomi dan Bisnis \\ Universitas Mataram, Indonesia
}

\author{
Lalu Hamdani Husnan ${ }^{3}$ \\ Fakultas Ekonomi dan Bisnis \\ Universitas Mataram, Indonesia
}

\begin{abstract}
ABSTRAK
Bentuk manifestasi penerapan standar akuntansi pemerintahan adalah opiniWTP dari BPK. Penelitian ini bertujuan untuk menguji pengaruh pendidikan staf keuangan, pelatihan akuntansi, penggunaan aplikasai SAIBA, dan komitmen organisasi terhadap keberhasilan penerapan sistem akuntansi instansi berbasis akrual. Penelitianini dilakukan pada satuan kerja di lingkup Kan wil BPN Provinsi NTB. Responden berjumlah 63 orang. Teknik analisis data menggunakan analisis regresi linier berganda. Hasil penelitian menunjukkan bahwa komitmen organisasi berpengaruh positif, penggunaan aplikasi SAIBA berpengaruh negatif, namun pendidikan staf keuangan dan pelatihan akuntansi tidak berpengaruh terhadap keberhasilan penerapan sistem akuntansi instansi berbasis akrual.
\end{abstract}

Kata Kunci: Pendidikan Staf Keuangan; Pelatihan Akuntansi; SAIBA; Komitmen Organisasi; Sistem Akuntansi Instansi Berbasis Akrual.

\section{Determinants Of Success In The Application Of Accrual- Based Institution Accounting Systems In Preparing Government Financial Statements}

\begin{abstract}
The manifestation of the application of government accounting standards is the WTP opinion from BPK. This study aims to examine the effect of financial staff education, accounting training, the use of the SAIBA application, and organizational commitment to the successful application of an accrual-based accounting system. This research was conducted at the Land Office work unit within the scope of the NTB Province BPNRegional Office. Respondents numbered 63 people. Data analysis techniques used multiple linear regression analysis. The results showed that organizational commitment had a positive effect, the use of the SAIBA application had a negative effect, but financial staff education and accounting training had no effect on the successful application of the accrual-based agency accounting system.
\end{abstract}

Keywords: $\quad$ Financial StaffEducation; Accounting Training; SAIBA; Organizational Commitment; Accrual Based Institution Accounting System.

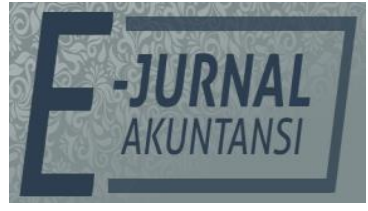

E-JA

e-Jurnal Akuntansi e-ISSN 2302-8556

Vol. 30 No. 6

Denpasar, Juni 2020

Hal.1522-1538

Artikel Masuk: 4 April 2020

Tanggal Diterima: 23 Juni 2020

The Article is Available in : https://ojs.unud.ac.id/index.php/Akuntansi/index 


\section{PENDAHULUAN}

Organisasi sektor publik di seluruh dunia telah terlibat dalam strategi perubahan kelembagaan, organisasi dan manajerial dalam rangka memenuhi kebutuhan yang semakin meningkat akan akuntabilitas keuangan, efisiensi dan efektifitas. Perubahan tersebut menjadikan sistem manajemen tradisional sektor publik yang awalnya terkesan birokratis, kaku dan hierarkis menjadi manajemen sektor publik yang fleksibel dan lebih mengakomodasi pasar dan serba terdigitalisasi Yuhelson et al. (2020). Perubahan manajemen sektor publik tersebut kemudian dikenal dengan istilah New Public Management (Kusuma \& Fuad 2013). NPM adalah konsep yang digunakan secara luas yang menjelaskan transposisi teknik manajemen sektor swasta dan mekanisme yang berorientasi pasar ke sektor publik (Awasom 2019). Tujuan New Public Management adalah untuk merubah administrasi publik sehingga kualitas laporan keuangan pemerintah akan seperti perusahaan dan tergitilaisasi Yuhelson et al. (2020). Instansi pemerintah sebagai penyedia jasa bagi masyarakat harus sadar akan tugasnya untuk menghasilkan layanan yang efisien dan efektif namun di lain pihak tidak boleh berorientasi pada laba (Kristiawati 2015).

Praktik NPM yang mendasari pada teori ekonomi merupakan alasan dilakukannya adopsi sistem akuntansi akrual pada organisasi sektor publik (Herwiyanti et al., 2017). Diyakini bahwa ini adalah metode yang tepat untuk mencapai keterbandingan, transparansi, dan akuntabilitas di sektor publik (K. Matekele \& V. Komba 2020). Perubahan basis akuntansi ini bertujuan untuk mempromosikan sektor swasta dalam pembangunan ekonomi dan menempatkan sektor publik dalam persaingan dengan sektor swasta (Abeysinghe \& Samanthi 2016).

Di Indonesia, gerakan akuntansi menuju berbasis akrual dimulai sejak gerakan reformasi tahun 1998 dan ditetapkannya undang - undang nomor 17 Tahun 2003 tentang Keuangan Negara (Erawati \& Kurniawan 2018). Perubahan basis akuntansi ini terjadi tidak hanya di tingkat pemerintah pusat tetapi juga di tingkat pemerintah daerah (Karunia et al., 2019). Berlakunya Peraturan Pemerintah Nomor 71 Tahun 2010 tentang SAP berbasis akrual sebagai pengganti Peraturan Pemerintah Nomor 24 Tahun 2005 membawa perubahan besar dalam sistem pelaporan keuangan di Indonesia, yaitu perubahan dari basis kas menuju akrual menjadi basis akrual penuh dalam pengakuan transaksi keuangan pemerintah (Lamonisi 2016). Peraturan ini dibuat untuk meningkatkan akuntabilitas dan transparansi di sektor pemerintah di Indonesia (Vertiarani \& Halim 2019). Dalam Peraturan Pemerintah No. 71 Tahun 2010, disebutkan juga bahwa akuntansi akrual adalah praktik terbaik di dunia internasional dan perlu diterapkan untuk meningkatkan kualitas informasi pelaporan keuangan pemerintah (Savitri \& Fanani 2017).

Bentuk pertanggungjawaban APBN / APBD adalah laporan keuangan yang harus sesuai dengan standar akuntansi pemerintah (Maimunah 2016). Dalam teori pendekatan kegunaan keputusan (decision usefullness aproach theory) dijelaskan bahwa entitas harus memberikan informasi yang dibutuhkan oleh stakeholders. Menurut Scott (2003:52) teori kegunaan keputusan (decision usefulness) merupakan suatu pendekatan terhadap laporan keuangan yang memiliki pandangan bahwa apabila laporan keuangan tidak bisa disiapkan 
secara teoritis berkonsep benar, paling tidak dapat disusun laporan keuangan historis yang lebih bermanfaat.

Akuntansi akrual adalah metode akuntansi yang mengukur kinerja keuangan dan posisi keuangan suatu entitas dengan mengenali efek dari suatu transaksi atau peristiwa yang terjadi terlepas dari waktu pembayaran tunai dilakukan (Nadiah Ahmad 2016). Akuntansi berbasis akrual tidak dimaksudkan untuk menggantikan akuntansi berbasis kas, laporan realisasi anggaran masih didasarkan pada modal dan pengeluaran saat ini (Biondi 2016). Pengguna informasi akan diinformasikan tidak hanya tentang transaksi masa lalu, tetapi juga dengan informasi tentang kewajiban yang harus diselesaikan di masa depan dan tentang aset yang uangnya akan diterima di masa depan (Elmezughi \& Wakil 2018).

Suatu pemerintahan yang menerapkan Standar Akuntansi Pemerintahan akan menghasilkan laporan keuangan yang sangat diperlukan dalam lingkungan pemerintahan (Triwahyuni, Nurazlina, \& Silfi 2016). Kebutuhan informasi tentang kegiatan operasional pemerintahan serta posisi kekayaan dan kewajiban dapat dipenuhi dengan lebih baik dan memadai apabila didasarkan pada basis akrual, yakni berdasarkan pengakuan munculnya hak dan kewajiban, bukan berdasarkan pada arus kas semata (PP 71, 2010). Penyajian informasi laporan keuangan yang sesuai dengan manfaat atau kebutuhan tertentu akan membantu dalam proses pengambilan keputusan. Artinya, laporan keuangan yang dipublikasikan harus menunjukkan keadaaan yang sebenarnya sehingga stakeholders dapat mengambil keputusan atau kebijakan yang tepat.

Kelebihan penerapan basis akrual pada akuntansi pemerintahan, antara lain: (1) Memberikan gambaran bagaimana pemerintah membiayai aktivitasaktivitasnya dan memenuhi kebutuhan pendanaannya; (2) Memungkinkan pengguna laporan keuangan untuk mengevaluasi kemampuan pemerintah saat ini (Rahmawati, Made, \& Y 2016), (3) Laporan fiskal berbasis akrual memberikan pandangan yang lebih komprehensif tentang kinerja keuangan pemerintah dan biaya kegiatan pemerintah (Cavanagh, Flynn, \& Moretti 2016), (4) Meningkatkan transparansi tentang sumber daya publik dan konsumsi pemerintah (Wagnerkrechlok, Hilgers, \& Brixner 2019).

Pada tahun 2015 telah dibuat Aplikasi Akuntansi Instansi Berbasis Akrual (SAIBA) yang dikembangkan oleh Kementerian Keuangan untuk mendukung pelaksanaan sistem akuntansi berbasis akural. Proses bisnis aplikasi ini dimulai dari perekaman dokumen baik secara manual maupun secara elektronik sehingga terbentuk jurnal transaksi (Wahyudi 2019), namun ternyata bukan hal mudah bagi pemerintah untuk menerapkan basis akrual secara penuh. Hal ini karena kesiapan dan koordinasi seluruh unit entitas akuntansi, unit entitas pelaporan, unit perbendaharaan dan unit penyusun standar akuntansi untuk melaksanakan peran dan kewenangan masing-masing dalam penerapan akuntansi berbasis akrual secara penuh yang tentunya membutuhkan waktu yang tidak singkat untuk mewujudkannya (Iskandar, Amriani, and Subekan 2016).

Kompleksitas akuntansi berbasis akrual merupakan salah satu hal yang menjadi hambatan dan menjadi salah satu alasan timbulnya penolakan terhadap perubahan basis akuntansi. Diperlukan waktu bertahun-tahun bagi instansi 
pemerintah pusat untuk beradaptasi terhadap perubahan tersebut. Proses adaptasi ini berjalan lambat karena perubahan yang terjadi dalam proses penyusunan laporan keuangan cukup drastis dan memerlukan pemahaman atas basis akuntansi yang baru cukup lama, karena metode pembukuan yang berbeda (www.dpr.go.id, 2015).

Menurut Ichsan (2013) salah satu keberhasilan dari penerapan akuntansi akrual pada akhirnya dapat dilihat dalam opini dari hasil pemeriksaan atas laporan keuangan. Nasution (2008:49) menyampaikan bahwa terdapat 6 (enam) langkah (komponen) yang perlu diperhatikan agar laporan keuangan pemerintah mendapatkan opini Wajar Tanpa Pengecualian (WTP) yaitu: (1) Sistem pembukuan dan perencanaan anggaran, (2) Sistem aplikasi teknologi komputer (IT related), (3) Inventarisasi aset dan utang, (4) Jadwal waktu penyusunan laporan keuangan dan pemeriksaan serta pertanggungjawabkan anggaran, (5) Quality assurance yang dilakukan oleh pengawas intern, (6) Sumber daya manusia.

Kementerian Agraria dan Tata Ruang/Badan Pertanahan Nasional adalah salah satu Instansi Pemerintah yang telah mendapatkan opini Wajar Tanpa Pengecualian (WTP) dari Badan Pemeriksa Keuangan selama 6 (enam) tahun berturut-turut dari tahun 2013 sampai 2018 (BPK 2018).

Kesuksesan penerapan SAP berbasis akrual sangat diperlukan sehingga pemerintah dapat menghasilkan laporan keuangan yang lebih transparan dan lebih akuntabel. Jelas sekali untuk membuat penerapan ini berjalan baik, dibutuhkan proses, kondisi dan faktor-faktor yang dapat membuat penerapan ini berjalan seperti yang diharapkan seperti kapabilitas sumber daya manusia yang terlibat dalam pelaporan keuangan, komitmen pimpinan dan seluruh staf, serta teknologi informasi yang mendukung sistem akuntansi untuk mengolah data dengan lebih cepat dan akurat (Putri 2016).

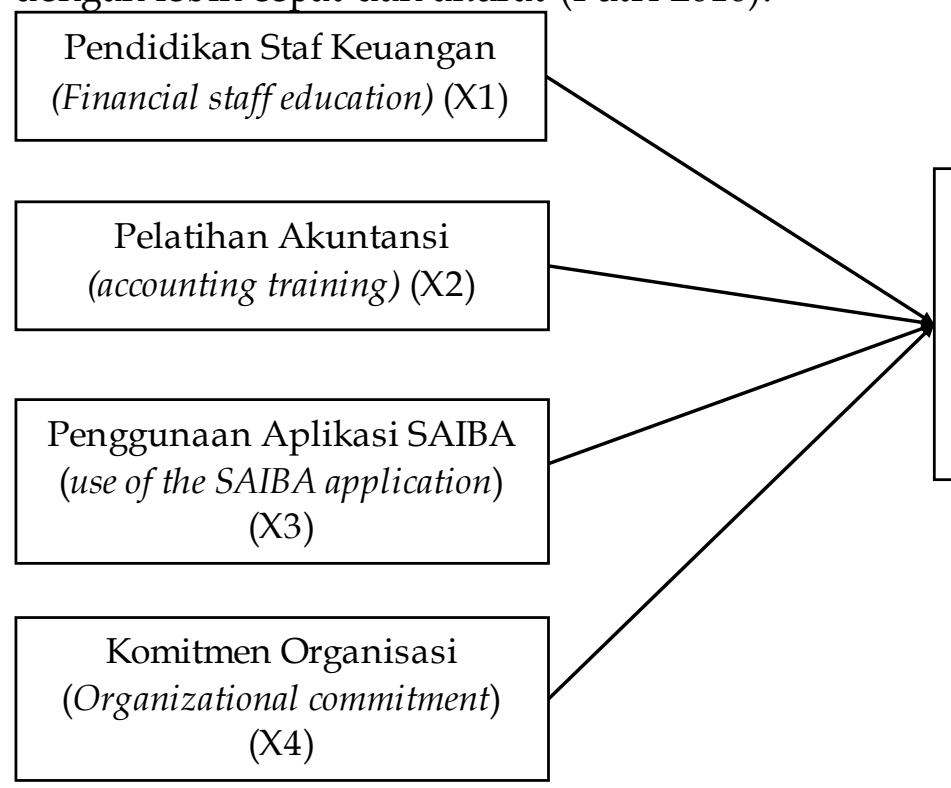

Keberhasilan Penerapan Sistem Akuntansi Instansi Berbasis Akrual (the successful application of the accrual-based agency accounting system $)(\mathrm{Y})$

Sumber: Data Penelitian, 2020

Gambar 1. Model Penelitian 
Perubahan organisasi sektor publik sebagai bentuk penerapan New Public Management menjadikan sistem manajemen tradisional sektor publik menjadi manajemen yang lebih terbuka dan fleksibel terhadap pasar. Dampak dari perubahan tersebut salah satunya adalah penerapan standar akuntasi pemerintahan berbasis akrual. Perubahan basis akuntansi ini menuntut kesiapan dari pemerintah itu sendiri terutama dari sisi kualitas sumberdaya manusia. Menurut Shawallizayusof \& Jaafar (2018) kompetensi sumber daya manusia, kemampuan perangkat lunak dan teknologi, kebijakan akuntansi, dan kesesuaian standar diidentifikasi sebagai tantangan utama dalam upaya implementasi.

Sumber daya manusia dengan latar belakang pendidikan akuntansi atau setidaknya memiliki pengalaman di bidang keuangan sangat dibutuhkan dalam suatu pekerjaan yang berhubungan dengan penyusunan laporan keuangan. Namun akhir-akhir ini terdapat permasalahan terkait latar belakang pendidikan dalam penyusunan laporan keuangan pemerintah. Masalah-masalah tersebut adalah belum dimilikinya atau kurangnya sumber daya manusia berlatar pendidikan akuntansi, belum ada kebijakan rekruitmen pegawai berlatar belakang akuntansi, dan adanya anggapan bahwa sumber daya manusia yang bukan berlatar belakang akuntansi mampu melaksanakan tugas dengan modal pendidikan dan pelatihan (diklat) dan bimbingan (Wibowo 2013). Menurut Wahyuni \& Adam (2015) sumberdaya manusia yang memiliki peran penting dalam penerapan basis akrual ini, akan mengalami kesulitan ketika mereka bukan berasal dari background akuntansi maupun ekonomi.

Pengelola Keuangan yang memiliki pendidikan akuntansi sangat dibutuhkan dalam suatu pekerjaan yang berhubungan dengan penyusunan laporan keuangan. Menurut Sinambela (2018:168) apabila organisasi memiliki Sumber Daya Manusia (SDM) yang profesional, berkualitas, berkomitmen, dan berintegritas yang baik dipastikan organisasi tersebut dapat berkembang dengan pesat. Nazier (2009) menyatakan Tingkat Pendidikan mempunyai peran yang sangat penting karena dengan pengetahuan yang diperoleh dari pendidikan dalam proporsi tertentu dapat memenuhi syarat-syarat yang dituntut oleh suatu pekerjaan sehingga pekerjaan dapat diselesaikan dengan lebih cepat dan tepat.

Penelitian yang dilakukan oleh Widianti et al. (2016) menunjukkan bahwa tingkat pendidikan staf keuangan terbukti berpengaruh terhadap penerapan akuntansi akrual. Selaras dengan hasil penelitian tersebut, penelitian yang dilakukan oleh Eriotis et al. (2011) juga menunjukkan yaitu tingkat pendidikan staf keuangan berpengaruh positif terhadap penerapan akuntansi akrual. Begitu juga penelitian yang dilakukan oleh Stamatiadis \& Eriotis (2011) membuktikan bahwa tingkat pendidikan staf akuntansi dan keuangan berpengaruh terhadap penerapan akuntansi akrual. Berdasarkan tinjauan teoritis dan penelitian terdahulu maka dapat dirumuskan hipotesis sebagai berikut :

$\mathrm{H}_{1}$ : Pendidikan Staf Keuangan berpengaruh positif terhadap Keberhasilan Penerapan Sistem Akuntansi Instansi Berbasis Akrual.

Dalam teori pendekatan kegunaan keputusan (decision usefullness aproach theory) dijelaskan bahwa entitas harus memberikan informasi yang dibutuhkan oleh stakeholders. Penyajian informasi laporan keuangan yang sesuai dengan manfaat atau kebutuhan tertentu akan membantu dalam proses pengambilan 
keputusan. Penguasaan terhadap beban kerja yang dimiliki akan meningkatkan produktifitas kerja seseorang. Dengan produktifitas yang tinggi penyelesaian pekerjaan dengan benar dan sesuai waktu yang ditentukan akan dapat tercapai. Melalui pelatihan tingkat produktifitas seseorang dapat ditingkatkan. Semakin banyak pelatihan yang diikuti maka keberhasilan SAP Akrual semakin mudah penerapannya. Pelatihan dilakukan dengan alasan untuk meningkatkan pengetahuan pegawai tentang kompetitor dan budaya, membantu memastikan bahwa pegawai mempunyai keahlian dasar untuk bekerja dengan teknologi baru, membantu pegawai mengerti bagaimana bekerja secara efektif di dalam tim untuk berkontribusi dalam produksi dan kualitas pelayanan, serta mempersiapkan pegawai untuk menerima dan bekerja secara efektif satu sama lain. Menurut Sinambela (2018:167) pelatihan dapat membantu pegawai dalam mengembangkan berbagai keterampilan yang dibutuhkan untuk menjalankan organisasinya, yang secara langsung akan mempengaruhi pekerjaan yang sedang dilakukannya.

Penelitian yang dilakukan oleh Kusuma \& Fuad (2013) menunjukkan bahwa pelatihan staf keuangan terbukti berpengaruh positif terhadap tingkat penerapan akuntansi akrual. Temuan ini didukung oleh hasil penelitian yang dilakukan oleh Eriotis et al. (2011) bahwa pelatihan berpengaruh positif terhadap penerapan akuntansi akrual. Adapun Najati et al. (2016) dalam penelitiannya juga membuktikan hal yang sama bahwa pelatihan akuntansi berpengaruh terhadap implementasi akuntansi berbasis akrual. Berdasarkan tinjauan teoritis dan penelitian terdahulu maka dapat dirumuskan hipotesis sebagai berikut :

$\mathrm{H}_{2}$ : Pelatihan Akuntansi berpengaruh positif terhadap Keberhasilan Penerapan Sistem Akuntansi Instansi Berbasis Akrual.

Teori New Public Management menyatakan bahwa perbaikan secara terus menerus telah dilakukan pemerintah salah satunya dengan meningkatkan kualitas teknologi sistem informasi untuk mendukung tercapainya peningkatan kualitas laporan keuangan. Pengembangan aplikasi SAKPA menjadi aplikasi SAIBA merupakan terobosan aplikasi akuntansi instansi berbasis akrual yang diharapkan memenuhi kebutuhan informasi laporan keuangan yang disyaratkan dalam standar akuntansi pemerintahan. Ouda (2004) dalam penelitiannya menyatakan bahwa kapabilitas teknologi informasi adalah syarat dasar dalam kesuksesan penerapan akuntansi akrual di sektor pemerintah. Adapun Ichsan (2013) juga menyatakan bahwa kapabilitas teknologi informasi dan komunikasi merupakan kunci sukses keberhasilan pelaksanaan implementasi basis akrual. Yudi et al., (2016) dalam penelitiannya menyatakan bahwa sistem aplikasi mengurangi peran aparatur dengan latar belakang akademik akuntansi dalam penerapan basis akrual.

Penelitian yang dilakukan oleh Eriotis et al., (2011) membuktikan bahwa kualitas teknologi informasi berpengaruh positif terhadap penerapan akuntansi akrual. Sejalan dengan temuan tersebut, penelitian Stamatiadis \& Eriotis (2011) menunjukkan bahwa sistem teknologi informasi berpengaruh terhadap penerapan akuntansi akrual. Hasil penelitian ini juga didukung oleh penelitian Witantri (2012) bahwa perangkat pendukung berpengaruh signifikan terhadap penerapan SAP berbasis akrual. Kristyono et al. (2014) dalam penelitiannya juga membuktikan bahwa perangkat pendukung berpengaruh terhadap keberhasilan 
pengelolaan keuangan daerah menggunakan standar akuntansi pememerintah. Penelitian Nitzl et al. (2020) menyatakan bahwa sistem teknologi informasi berperan penting dalam penerapan basis akrual. Berdasarkan tinjauan toeritis dan penelitian terdahulu maka dapat dirumuskan hipotesis sebagai berikut : $\mathrm{H}_{3}$ : Penggunaan Aplikasi SAIBA berpengaruh positif terhadap Keberhasilan Penerapan Sistem Akuntansi Instansi Berbasis Akrual.

Untuk mewujudkan penerapan basis akrual bukanlah sesuatu yang mudah, hal ini karena kesiapan dan koordinasi seluruh unit entitas akuntansi, unit entitas pelaporan, unit perbendaharaan dan unit penyusun standar akuntansi untuk melaksanakan peran dan kewenangan masing-masing dalam penerapan akuntansi berbasis akrual secara penuh yang tentunya membutuhkan waktu yang tidak singkat untuk mewujudkannya, untuk itu dibutuhkan komitmen yang kuat oleh seluruh pihak dalam suatu organisasi. Jika komitmen organisasi telah terbangun akan mendukung penerapan New Public Management dalam hal ini keberhasilan penerapan sistem akuntansi instansi berbasis akrual.

Veronica \& Krisnadewi (2009) menjelaskan bahwa komitmen organisasi adalah dorongan dari dalam diri karyawan untuk berbuat sesuatu agar dapat menunjang keberhasilan organisasi sesuai dengan tujuan dan lebih mengutamakan kepentingan organisasi. Menurut Supriyatno (2010) dalam penelitiannya menyatakan bahwa komitmen organisasi merupakan suatu kemampuan, keyakinan, kemauan, dan hasrat untuk mewujudkan tujuan organisasi. Komitmen organisasional menurut Eker (2007) merupakan suatu pengikut, yang memberi pengaruh pada tujuan dan nilai, serta kepentingan pada organisasi, terlepas dari instrumental yang semata-mata cukup, ditinjau dari konsep menurut tiga dimensi, yaitu identifikasi, keterlibatan, dan kesetiaan. Robbins (2001) mengemukakan bahwa komitmen karyawan pada organisasi merupakan salah satu sikap yang mencerminkan perasaan suka atau tidak suka seseorang karyawan terhadap organisasi tempat dia bekerja. Menurut Sopiah (2008:155) komitmen organisasional merupakan dimensi perilaku penting yang dapat digunakan untuk menilai kecenderungan karyawan untuk bertahan sebagai anggota organisasi.

Penelitian yang dilakukan oleh Witantri (2012) membuktikan bahwa komitmen berpengaruh signifikan terhadap penerapan SAP berbasis akrual. Sugiarto \& Alfian (2014) juga membuktikan bahwa komitmen berpengaruh terhadap keberhasilan penerapan akuntansi berbasis akrual. Selaras dengan temuan tersebut, Kristyono et al. (2014) juga berhasil membuktikan bahwa komitmen berpengaruh terhadap keberhasilan pengelolaan keuangan daerah menggunakan standar akuntansi pememerintah akrual. Berdasarkan tinjauan toeritis dan penelitian terdahulu maka dapat dirumuskan hipotesis sebagai berikut:

$\mathrm{H}_{4}$ : Komitmen Organisasi berpengaruh positif terhadap Keberhasilan Penerapan Sistem Akuntansi Instansi Berbasis Akrual.

Penerapan New Public Management melalui pengadopsian sistem swasta oleh pemerintah merupakan sebuah upaya untuk meningkatkan kualitas kinerja pemerintah. Salah satu bentuk penerapannya adalah dengan peningkatan kapabilitas sumberdaya manusia melalui rekrutmen pegawai berbasis kompetensi serta peningkatan kapasitas SDM melalui pelatihan-pelatihan 
berbasis akuntansi. Sejalan dengan itu, dalam rangka mencapai laporan keuangan berbasis akrual pemerintah telah menciptakan perangkat pendukung. Aplikasi SAIBA memiliki fitur tambahan untuk menunjang penginputan transaksi-transaksi akrual. Melalui penerapan akuntansi berbasis akrual akan meningkatkan kualitas laporan keuangan pemerintah dan diharapkan dapat memberikan informasi yang dibutuhkan oleh stakeholder ssesuai dengan decision usefullness aproach theory. Beberapa faktor yang menjadi perhatian peneliti adalah Tingkat Pendidikan, Pelatihan Akuntansi, Penggunaan Aplikasi SAIBA, dan Komitmen Organisasi. Keempat faktor ini secara teori berperan dalam keberhasilan pelaksanaan Sistem Akuntansi Instansi Berbasis Akrual. Penting untuk dilakukan pengujian pengaruh dari keempat faktor tersebut secara bersama-sama terhadap keberhasilan Impelementasi Sistem Akuntansi Instansi Berbasis Akrual. Berdasarkan tinjauan toeritis maka dapat dirumuskan hipotesis sebagai berikut:

$\mathrm{H}_{5}$ : Pendidikan Staf Keuangan, Pelatihan Akuntansi, Penggunaan Aplikasi SAIBA, dan Komitmen Organisasi berpengaruh secara bersama-sama terhadap Keberhasilan Penerapan Sistem Akuntansi Instansi Berbasis Akrual.

\section{METODE PENELITIAN}

Menurut Sugiyono (2014:6) dikemukakan bahwa "yang termasuk dalam metode kuantitatif adalah metode penelitian survey", oleh karena itu penelitian ini menggunakan metode kuantitatif. Metode kuantitatif dapat diartikan sebagai metode penelitian yang berlandaskan pada filsafat positivisme, digunakan untuk meneliti pada populasi atau sampel tertentu, pengumpulan data menggunakan instrumen penelitian, analisis data bersifat kuantitatif/ statistik, dengan tujuan untuk menggambarkan dan menguji hipotesis yang telah ditetapkan (Sugiyono, 2017:15).

Lokasi penelitian dilakukan pada satuan kerja Kementerian Agraria dan Tata Ruang/BPN se-Provinsi NTB. Populasi dalam penelitian ini adalah sebanyak 143 orang yang merupakan Aparatur Sipil Negara (ASN) bagian Pengelola APBN dan Sistem Akuntansi Instansi (SAI) pada 11 (sebelas) satuan kerja di Kantor Wilayah BPN dan Kantor Pertanahan Kab/Kota se-Provinsi Nusa Tenggara Barat. Adapun sampel dalam penelitian ini berjumlah 68 orang yang dipilih dengan metode purposive sampling yaitu Aparatur Sipil Negara (ASN) yang ditetapkan melalui keputusan kepala kantor sebagai Pengelola Sistem Akuntansi Instansi (SAI) pada 11 (sebelas) satuan kerja di Kantor Wilayah BPN dan Kantor Pertanahan Kab/Kota se-Provinsi Nusa Tenggara Barat.

Variabel independen dalam penelitian ini adalah Pendidikan Staf Keuangan, Pelatihan Akuntansi, Penggunaan Apliksasi SAIBA, dan Komitmen Organisasi. Variabel terikat dalam penelitian ini adalah Keberhasilan Penerapan Sistem Akuntansi Intansi Berbasis Akrual. Dalam penelitian ini, peneliti menggunakan jenis instrumen angket atau kuesioner. Angket yang digunakan dalam penelitian ini adalah angket tertutup, dimana pernyataan telah memiliki alternatif jawaban (option) yang tinggal dipilih oleh responden. 


\section{HASIL DAN PEMBAHASAN}

Responden didominasi oleh pria sebesar 59\% sementara wanita sebesar $41 \%$. Hal ini menunjukkan bahwa kepala satuan kerja mengharapkan mobilitas yang lebih tinggi dalam pekerjaan di bidang akuntansi dan pelaporan. Namun jika melihat proporsi jumlah ASN wanita yang cukup tinggi yaitu sebesar $41 \%$ mungkin disebabkan karena penyusunan laporan keuangan membutuhkan ketelitian yang cukup tinggi sehingga sesuai untuk pekerjaan yang bersifat administratif.

Adapun dalam hal usia responden terbagi menjadi 3 rentang usia. Pertama, usia 25 -35 tahun dengan jumlah 26 orang atau $41 \%$ dari keseluruhan responden. Kedua, usia 36 - 45 tahun dengan jumlah 19 orang atau 30\% dari keseluruhan responden. Ketiga, usia $>45$ tahun dengan jumlah 18 orang atau $29 \%$ dari keseluruhan responden. Dominasi usia 25-35 tahun menunjukkan bahwa penetapan pengelola SAI telah mempertimbangkan kemampuan fisik karena rentang usia tersebut merupakan usia produktif seseorang untuk melaksanakan kegiatan terutama yang membutuhkan tingkat ketelitian tinggi. Pada rentang usia ini pada umumnya adalah staf pengelola keuangan yang bertugas dalam pengumpulan data, pencatatan, dan pengikhtisaran.

Pendidikan responden paling banyak pada tingkat S1 (sarjana) sejumlah 30 orang atau $48 \%$ dari keseluruhan responden, disusul dengan pendidikan S2 (Master) di urutan kedua sejumlah 15 orang atau 24\% dari keseluruhan responden. Hal ini mengindikasikan bahwa rata-rata responden memiliki kemampuan akademis yang cukup.

Dari sisi masa kerja responden dibagi menjadi 4 kelompok, yaitu masa kerja dibawah 5 tahun, masa kerja antara 5 sampai 10 tahun, masa kerja 11 sampai 20 tahun, dan masa kerja diatas 20 tahun. Masa kerja rentang 5 sampai 10 tahun mendominasi dengan jumlah 23 orang atau $37 \%$ dari keseluruhan responden, disusul oleh responden dengan masa kerja $>20$ tahun dengan sebagai posisi kedua. Hal ini menunjukkan bahwa pengelola SAI pada 11 satuan kerja Kantor Pertanahan memiliki pengalaman dalam bidang pekerjaannya.

Tabel 1. Hasil Regresi Linear Berganda

\begin{tabular}{|c|c|c|c|c|c|}
\hline \multirow[t]{2}{*}{ Model } & \multicolumn{2}{|c|}{$\begin{array}{l}\text { Unstandardized } \\
\text { Coefficients }\end{array}$} & \multirow{2}{*}{$\begin{array}{l}\text { Standardized } \\
\text { Coefficients } \\
\text { Beta }\end{array}$} & \multirow[t]{2}{*}{$\mathrm{t}$} & \multirow[t]{2}{*}{ Sig. } \\
\hline & B & Std. Error & & & \\
\hline (Constant) & 30,859 & 5,534 & & 5,577 & 0,000 \\
\hline Pendidikan Staf Keuangan $\left(\mathrm{X}_{1}\right)$ & 0,151 & 0,100 & 0,187 & 1,521 & 0,134 \\
\hline Pelatihan Akuntansi $\left(\mathrm{X}_{2)}\right.$ & 0,171 & 0,119 & 0,213 & 1,438 & 0,156 \\
\hline Penggunaan Aplikasi SAIBA $\left(\mathrm{X}_{3}\right)$ & $-0,586$ & 0,147 & $-0,501$ & $-3,987$ & 0,000 \\
\hline Komitmen Organisasi $\left(\mathrm{X}_{4)}\right.$ & 0,443 & 0,092 & 0,556 & 4,826 & 0,000 \\
\hline Adjusted R Square & & 0,389 & & & \\
\hline Sig. F & & 0,000 & & & \\
\hline
\end{tabular}

Sumber: Data Penelitian, 2020

Dari hasil pengujian menggunakan SPSS diperoleh adjusted $\mathrm{R}^{2}$ sebesar 0,389. Artinya 38,7\% variasi keberhasilan penerapan sistem akuntansi instansi berbasis akrual dapat dijelaskan oleh variasi dari keempat variabel independen yaitu Pendidikan Staf Keuangan, Pelatihan Akuntansi, Penggunaan Aplikasi SAIBA, dan Komitmen Organisasi. Sedangkan sisanya $(100 \%-38,7 \%=62,3 \%)$ dijelaskan oleh variabel lain diluar model regresi. Menurut Ghozali (2016) secara umum koefisien determinasi untuk data silang (crossection) relatif rendah karena 
adanya variasi yang besar antara masing-masing pengamatan, sedangkan untuk data runtun waktu (time series) biasanya mempunyai nilai koefisien determinasi yang tinggi.

Hipotesis pertama menyatakan bahwa semakin tinggi pendidikan staf keuangan maka akan semakin tinggi tingkat keberhasilan penerapan sistem akuntansi instansi berbasis akrual. Hasil pengujian terhadap hipotesis pertama menunjukkan bahwa pendidikan staf keuangan tidak berpengaruh positif terhadap keberhasilan penerapan sistem akuntansi instansi berbasis akrual. Nilai t-statistik pendidikan staf keuangan terhadap penerapan sistem akuntansi instansi berbasis akrual adalah 1,521. Nilai ini lebih kecil dari nilai $t$ tabel dengan derajat kepercayaan 95\% sebesar 2,002. Adapun hasil uji signifikansi (p-value) variabel pendidikan staf keuangan menunjukkan nilai 0,134 yang berarti lebih besar dari 0,05. Hasil uji ini menunjukkan bahwa pada taraf $5 \%$ pendidikan staf keuangan memiliki pengaruh yang positif namun tidak signifikan terhadap keberhasilan penerapan sistem akuntansi instansi berbasis akrual. Hasil ini berbeda dengan hipotesis yang telah dirumuskan, oleh karena itu hipotesis pertama ditolak.

Hasil penelitian ini terkonfirmasi oleh penelitian Kusuma \& Fuad (2013) yang membuktikan bahwa tingkat pendidikan staf keuangan tidak berpengaruh terhadap penerapan akuntansi akrual. Namun temuan ini berbeda dengan hasil penelitian yang dilakukan oleh Widianti et al. (2016) yang menyatakan bahwa tingkat pendidikan staf keuangan terbukti berpengaruh terhadap penerapan akuntansi akrual. Begitu juga dengan penelitian Eriotis et al. (2011) bahwa tingkat pendidikan staf keuangan berpengaruh positif terhadap reformasi akuntansi akrual.

Tidak signifikannya hubungan antara variabel pendidikan staf keuangan dengan variabel keberhasilan penerapan sistem akuntansi instansi berbasis akrual disebabkan karena sebagian besar staf di bagian keuangan rata-rata adalah lulusan SMA dan diploma. Walaupun dalam hasil penelitian ini hipotesis pertama ditolak, namun hasil penelitian ini masih sejalan dan mendukung teori New Public Management. Hal ini dikarenakan variabel independen pendidikan staf keuangan dan variabel dependen keberhasilan penerapan sistem akuntansi instansi berbasis akrual memiliki hubungan yang positif/searah. Hasil statistik deskriptif juga mengkonfirmasi bahwa rata-rata responden menyetujui bahwa latar belakang pendidikan memberikan nilai tambah dalam penyusunan laporan keuangan, bahkan responden juga menyetujui bahwa pendidikan akuntansi diwajibkan dalam penyusunan laporan keuangan

Hipotesis kedua menyatakan bahwa semakin tinggi frekuensi pelatihan akuntansi maka akan semakin tinggi pula tingkat keberhasilan penerapan sistem akuntansi instansi berbasis akrual. Hasil pengujian terhadap hipotesis kedua menunjukkan bahwa pelatihan akuntansi tidak berpengaruh positif terhadap keberhasilan penerapan sistem akuntansi instansi berbasis akrual. Nilai t-statistik pendidikan staf keuangan terhadap penerapan sistem akuntansi instansi berbasis akrual adalah 1,438. Nilai ini lebih kecil dari nilai $t$ tabel dengan derajat kepercayaan 95\% sebesar 2,002. Dengan derajat kepercayaan 95\% maka alpa sebesar $5 \%$ atau 0,05 . Adapun hasil uji signifikansi ( $p$-value) variabel pelatihan akuntansi menunjukkan nilai 0,156 yang berarti lebih besar dari 0,05. Oleh 
karena itu hipotesis kedua ditolak, yaitu pelatihan akuntansi tidak berpengaruh positifterhadap keberhasilan penerapan sistem akuntansi instansi berbasis akrual.

Hasil penelitian ini terkonfirmasi oleh penelitian Widianti et al. (2016) yang membuktikan bahwa pelatihan staf keuangan terbukti tidak berpengaruh terhadap penerapan akuntansi akrual. Namun temuan ini tidak selaras dengan hasil penelitian Kusuma \& Fuad (2013) yang menyatakan bahwa pelatihan staf keuangan berpengaruh terhadap penerapan akuntansi akrual. Begitu juga dengan penelitian Eriotis et al. (2011) menyatakan training berpengaruh positif terhadap accrual accounting reform. Adapun penelitian Najati et al. (2016) juga menyatakan bahwa pelatihan akuntansi berpengaruh terhadap penerapan akuntansi akrual.

Tidak signifikannya hubungan antara pelatihan akuntansi terhadap keberhasilan penerapan sistem akuntansi instansi berbasis akrual disebabkan karena tidak semua pengelola SAI telah mendapatan pelatihan akuntansi yang dibutuhkan dalam penyusunan laporan keuangan berbasis akrual. Pelatihan akuntansi yang diselenggarakan oleh Kementerian Keuangan biasanya dilaksanakan hanya beberapa kali dalam setahun. Keterbatasan anggaran pada satuan kerja mungkin menjadi kendala dilaksanakannya pelatihan-pelatihan di bidang akuntansi dan pelaporan. Walaupun hipotesis kedua ditolak namun hasil penelitian ini menunjukkan bahwa terdapat hubungan positif/searah antara variabel pelatihan akuntansi dan variabel keberhasilan penerapan sistem akuntansi instansi berbasis akrual. Untuk mencapai laporan keuangan yang berkualitas dibutuhkan kemampuan yang baik dalam penyusunan laporan keuangan. Kompleksitas basis akrual menuntut adanya peningkatan kompetensi pegawai yang salah satunya dapat dicapai melalui pelatihan-pelatihan yang relevan. Hasil statistik deskriptif atas variabel pelatihan akuntansi menunjukkan bahwa rata-rata responden menjawab pelatihan akuntansi yang telah mereka dapatkan bermanfaat dalam menunjang kemampuan penyusunan laporan keuangan. Adapun materi-materi dalam pelatihan akuntansi yang telah didapatkan juga sangat relevan dengan pekerjaan di kantor khususnya penyusunan laporan keuangan berbasis akrual.

Hipotesis ketiga menyatakan bahwa semakin tinggi penggunaan aplikasi SAIBA maka akan semakin tinggi pula tingkat keberhasilan penerapan sistem akuntansi instansi berbasis akrual. Hasil pengujian terhadap hipotesis ketiga menunjukkan bahwa penggunaan aplikasi SAIBA tidak berpengaruh positif terhadap keberhasilan penerapan sistem akuntansi instansi berbasis akrual. Nilai t-statistik penggunaan aplikasi SAIBA terhadap penerapan sistem akuntansi instansi berbasis akrual adalah-3,987. Nilai ini lebih kecil dari nilai t tabel dengan derajat kepercayaan $95 \%$ sebesar 2,002 Namun jika melihat hasil uji signifikansi (p-value) dengan derajat kepercayaan 95\% dan alpa sebesar 5\% atau 0,05, variabel penggunaan aplikasi SAIBA memperoleh nilai 0,000 yang berarti lebih kecil dari 0,05. Hal ini menunjukkan penggunaan aplikasi SAIBA berpengaruh terhadap keberhasilan penerapan sistem akuntansi instansi berbasis akrual. Namun karena arah hubungan negatif maka hipotesis ketiga ditolak, yaitu pelatihan akuntansi tidak berpengaruh positif terhadap keberhasilan penerapan sistem akuntansi instansi berbasis akrual. 
Hasil pengujian ini terkonfirmasi oleh penelitian Widianti et al. (2016) bahwa penggunaan aplikasi SAIBA tidak berpengaruh terhadap implementasi akrual. Penelitian ini juga sejalan dengan penelitian Kusuma \& Fuad (2013), Najati et al. (2016), Sugiarto \& Alfian (2014) yang menyatakan bahwa kualitas teknologi informasi terbukti tidak berpengaruh terhadap penerapan akuntansi akrual. Namun hasil dalam penelitian ini tidak sejalan dengan beberapa hasil penelitian sebelumnya yaitu penelitian Eriotis et al. (2011) yang membuktikan bahwa kualitas teknologi informasi berpengaruh terhadap penerapan akuntansi berbasis akrual. Penelitian Stamatiadis \& Eriotis (2011), Ichsan (2013), Kristyono et al. (2014), dan Ouda (2004) juga membuktikan bahwa kapabilitas teknologi informasi dan komunikasi berpengaruh terhadap penerapan basis akrual.

Penolakan hipotesis ketiga dimana penggunaan aplikasi SAIBA tidak berpengaruh positif terhadap keberhasilan penerapan sistem akuntansi instansi berbasis akrual disebabkan karena penggunaan aplikasi SAIBA yang kurang maksimal. Penggunaan aplikasi yang kurang maksimal dapat disebabkan karena kurangnya pengetahuan operator tentang penyusunan jurnal penyesuaian dapat berakibat pada kesalahan dalam penginputan transaksi akrual sehingga laporan keuangan tidak mencerminkan keadaan yang sebenarnya. Selain itu penolakan hipotesis ini juga dapat disebabkan karena pengembangan aplikasi SAIBA yang tidak melibatkan pengguna. Pengembangan aplikasi SAIBA dilakukan langsung oleh programer di tingkat pusat tanpa melibatkan pengguna di daerah sehingga setiap update/ pengembangan aplikasi SAIBA dilakukan tanpa mempertimbangan kebutuhan pengguna/operator.

Hipotesis keempat menyatakan bahwa semakin tinggi komitmen organisasi maka akan semakin tinggi pula tingkat keberhasilan penerapan sistem akuntansi instansi berbasis akrual. Hasil pengujian terhadap hipotesis keempat menunjukkan bahwa komitmen organisasi berpengaruh positif terhadap keberhasilan penerapan sistem akuntansi instansi berbasis akrual. Nilai t-statistik komitmen organisasi terhadap penerapan sistem akuntansi instansi berbasis akrual adalah 4,826. Nilai ini lebih besar dari nilai $t$ tabel dengan derajat kepercayaan 95\% sebesar 2,002. Jika derajat kepercayaan 95\% maka alpa sebesar $5 \%$ atau 0,05. Adapun hasil uji signifikansi ( $\mathrm{p}$-value) variabel komitmen organisasi menunjukkan nilai 0,000 yang berarti lebih kecil dari 0,05. Oleh karena itu hipotesis keempat diterima, yaitu komitmen organisasi berpengaruh positif terhadap keberhasilan penerapan sistem akuntansi instansi berbasis akrual.

Hasil pengujian ini terkonfirmasi oleh penelitian Kristyono et al. (2014) yang menyatakan bahwa komitmen berpengaruh terhadap keberhasilan pengelolaan keuangan daerah menggunakan standar akuntansi pememerintah. Penelitian yang dilakukan oleh Sugiarto \& Alfian (2014) juga membuktikan bahwa faktor komitmen berpengaruh terhadap keberhasilan penerapan akuntansi instansi berbasis akrual. Selaras dengan hasil penelitian tersebut, penelitian Witantri (2012) berhasil membuktikan bahwa komitmen berpengaruh terhadap penerapan standar akuntansi pemerintahan berbasis akrual.

Diterimanya hipotesis keempat menunjukkan bahwa komitmen sangat berperan dalam keberhasilan penerapan sistem akuntansi instansi berbasis akrual. Temuan tersebut terkonfirmasi oleh hasil statistik deskriptif dimana ratarata responden menyatakan akan bekerja dengan sungguh-sungguh dalam 
organisasi. Selain itu rata-rata responden juga sependapat akan berusaha dan bekerja diatas batas normal demi kepentingan organisasi. Temuan ini mendukung teori New Public Management dimana salah satu karakteristik dari teori ini adalah lebih menekankan kepada kedisiplinan yang tinggi. Kedisiplinan yang tinggi tidak akan tercapai tanpa adanya komitmen yang kuat dari aparatur sipil negara sebagai ujung tombak dalam pelaksanaan sistem akuntansi instansi berbasis akrual di sektor pemerintahan

Hipotesis kelima menyatakan bahwa apabila pendidikan staf keuangan, pelatihan akuntansi, penggunaan aplikasi SAIBA, dan komitmen organisasi secara bersama-sama meningkat maka akan meningkatkan keberhasilan penerapan sistem akuntansi instansi berbasis akrual dalam penyusunan laporan keuangan pemerintah. Hasil pengujian terhadap hipotesis kelima menunjukkan bahwa pendidikan staf keuangan, pelatihan akuntansi, penggunaan aplikasi SAIBA, dan komitmen organisasi berpengaruh secara bersama-sama terhadap keberhasilan penerapan sistem akuntansi instansi berbasis akrual. Dari uji ANOVA atau uji $\mathrm{F}$ diperoleh nilai $\mathrm{F}$ hitung sebesar 10,864 dengan probabilitas 0,000. Jika derajat kepercayaan 95\% maka alpa sebesar 5\% atau 0,05. Karena probabilitas (signifikansi) jauh lebih kecil dari 0,05 maka model regresi dapat digunakan untuk memprediksi variabel Penerapan Sistem Akutansi Instansi Berbasis Akrual, atau dapat dikatakan bahwa Pendidikan Staf Keuangan (PS), Pelatihan Akuntansi (PA), Penggunaan Aplikasi SAIBA (AS), dan Komitmen Organisasi (KO) secara bersama-sama berpengaruh terhadap keberhasilan Penerapan Sistem Akuntansi Instansi Berbasis Akrual (AB). Oleh karena itu hipotesis kelima diterima, yaitu pendidikan staf keuangan, pelatihan akuntansi, penggunaan aplikasi SAIBA, dan komitmen organisasi berpengaruh secara bersama-sama terhadap keberhasilan penerapan sistem akuntansi instansi berbasis akrual.

Hasil penelitian ini memperkuat teori New Public Management dimana pendidikan staf keuangan, pelatihan akuntansi, penggunaan aplikasi SAIBA, dan komitmen organisasi berpengaruh secara bersama-sama terhadap keberhasilan penerapan sistem akuntansi instansi berbasis akrual. Reformasi bidang sumberdaya manusia dan teknologi informasi mewaikili karakteristik utama teori New Public Management dalam Wahyuni \& Adam (2015) yaitu (1) perbaikan kualitas secara terus menerus, dan (2) memiliki sistem informasi yang tepat. Tanpa adanya sumberdaya manusia yang kompeten dan dukungan teknologi informasi tentunya akan sulit bagi pemerintah untuk mengadopsi manajemen sektor swasta.

\section{SIMPULAN}

Pendidikan staf keuangan tidak berpengaruh positif terhadap penerapan sistem akuntansi instansi berbasis akrual. Hal ini disebabkan karena staf keuangan pada satuan kerja di Kantor Wilayah dan Kantor Pertanahan se-Provinsi Nusa Tenggara Barat rata-rata berpendidikan SMA dan diploma. Pelatihan akuntansi tidak berpengaruh positif terhadap penerapan sistem akuntansi instansi berbasis akrual. Hal ini disebabkan karena tidak semua staf keuangan telah mendapatkan pelatihan akuntansi yang dibutuhkan dalam penyusunan laporan keuangan berbasis akrual. Penggunaan aplikasi SAIBA berpengaruh signifikan namun 
negatif terhadap penerapan sistem akuntansi instansi berbasis akrual. Hal ini disebabkan karena kurang maksimalnya penggunaan aplikasi SAIBA karena kurangnya pemahaman operator/pengguna dalam penyusunan jurnal penyesuaian dan pengembangan aplikasi SAIBA yang tidak melibatkan pengguna. Komitmen organisasi berpengaruh (signifikan) positif terhadap penerapan sistem akuntansi instansi berbasis akrual. Pendidikan staf keuangan, pelatihan akuntansi, penggunaan aplikasi SAIBA, dan Komitmen Organisasi berpengaruh secara bersama-sama terhadap penerapan sistem akuntansi instansi berbasis akrual.

Nilai adjusted R2 menunjukkan masih terdapat variabel lain di luar model penelitian yang mempengaruhi keberhasilan penerapan sistem akuntansi instansi berbasis akrual, oleh karena itu penelitian selanjutnya disarankan untuk mempertimbangkan faktor-faktor sosial lain yang lebih luas dan mungkin memiliki pengaruh signifikan terhadap variabel keberhasilan penerapan sistem akuntansi instansi berbasis akrual misalnya seperti kebijakan pimpinan, sistem pengendalian internal, pengawasan auditor.

\section{REFERENSI}

Abeysinghe, Chandrasiri and Dinushika Samanthi. 2016. "Accrual Basis and Political Interest in Public Sector Accounting. The Case of a Municipal Council in Sri Lanka." International Journal of Academic Research in Accounting, Finance and Management Sciences 6(3):58-68.

Awasom, Susana Yene. 2019. "Institutionalizing Accrual Budgeting And Accounting Through A Uniform Legislation : Une Expérience Á La." Tékhne - Review of Applied Management Studies (2018):15-27.

Biondi, Yuri. 2016. "The HM 'Treasure's Island': The Application of AccrualsBased Accounting Standards in the UK Government." Accounting in Europe 13(1):81-102.

BPK. 2018. Laporan Hasil Pemeriksaan BPK RI.

Cavanagh, Joe, Suzanne Flynn, and Delphine Moretti. 2016. "Implementing Accrual Accounting in the Public Sector." International Monetary Fund 2016(06):1-56.

DPR-RI. 2015. "Persiapan Penerapan Akuntansi Berbasis Akrual Di Indonesia."

Eker, Melek. 2007. "The Impact of Budget Participation On Managerial Performance Via Organizational Commitment: A Study On The Top 500 Firm in Turky." Journal Ankara Universiti SBF.

Elmezughi, Abdalla and Amal Abdel Wakil. 2018. "Feasibility of Transformation to Accrual Basis of Accounting in the Public Sector: Kingdom of Bahrain Context." Academy of Accounting and Financial Studies Journal 22(6):1-16.

Erawati, Teguh and Danang Kurniawan. 2018. "Penerapan Sistem Akuntansi Berbasis Akrual: Kajian Dari Aspek Keperilakuan." Jurnal Ekonomi Dan Bisnis 21(2):313-32.

Eriotis, Nikolaos, Filippos Stamatiadis, and Dimitrious Vasiliou. 2011. “Assessing Accrual Accounting Reform in Greek Public Hospitals: An Empirical Investigation." Journal of Economic Policy (2116):0-33.

Ghozali, Imam. 2016. Aplikasi Analisis Multivariate. Semarang: Badan Penerbit Universitas Diponegoro. 
Herwiyanti, Eliada, Sukirman Sukirman, and Fairuz Sufi Aziz. 2017. “Analisis Implementasi Akuntansi Berbasis Akrual Pada Inspektorat Jenderal Kementerian Keuangan." Jurnal Akuntansi Dan Keuangan 19(1):13-23.

Ichsan, Muhammad. 2013. "Kajian-Kajian Variabel Kesuksesan Penerapan Basis Akrual Dalam Sistem Akuntansi Pemerintahan." Jurnal Akuntansi Pemerintah Berbasis Akrual Konsep, Pemikiran, Dan Implementasi Di Indonesia 122.

Iskandar, Azwar, Tenry Nur Amriani, and Achmat Subekan. 2016. "Evaluasi Atas Implementasi Aplikasi Sistem Akuntansi Instansi Basis Akrual (Saiba) Pada Mitra Kerja Kppn Gorontalo Dan Marisa." Jurnal Tata Kelola E Akuntabilitas Keuangan Negara 2(2):111.

K. Matekele, Charles and Gabriel V. Komba. 2020. "Factors Influencing Implementation of Accrual Based International Public Sector Accounting Standards in Tanzanian Local Government Authorities." Asian Journal of Economics, Business and Accounting 13(3):1-25.

Karunia, Asaprima Putra, Payamta Payamta, and Sutaryo Sutaryo. 2019. “The Implementation of Accrual-Based Accounting in Indonesian Government: Has Local Government Financial Statement Quality Improved?" Journal of Accounting and Investment 20(2).

Kristiawati, Endang. 2015. “Faktor-Faktor Yang Mempengaruhi Keberhasilan Penerapan Akuntansi Berbasis Akrual Pada Pemerintahan Daerah Kalimantan Barat." Jurnal Akuntabilitas 8(3):171-90.

Kristyono, Joko, Kharis Raharjo, and Rita Andini. 2014. "Faktor-Faktor Yang Mempengaruhi Keberhasilan Pengelolaan Keuangan Daerah Sesuai PP 71/2010 (Studi Pada Dinas Pendidikan Kota Semarang Tahun 2012/2013)."

Kusuma, Muhamad Indra Yudha and Fuad. 2013. "Analisis Faktor-Faktor Yang Mempengaruhi Tingkat Penerapan Akuntansi Akrual Pada Pemerintah." 2:1-14.

Lamonisi, Sony. 2016. “Analisis Penerapan Standar Akuntansi Berbasis Akrual Pada Pemerintah Kota Tomohon." 4(1):223-30.

Maimunah, Mutara. 2016. "Implementation of Accrual Accounting: Review of Readiness and Arising Problem." Procedia - Social and Behavioral Sciences 219:480-85.

Nadiah Ahmad, Nurul. 2016. "Investigating the Factors Influencing User s ' Resistance towards Accrual Accounting." Procedia Economics and Finance 35(October 2015):17-26.

Najati, Ida, Endar Pituringsih, and Animah. 2016. “Implementasi Akuntansi Berbasis Akrual: Pengujian Determinan Dan Implikasinya Terhadap Kualitas Laporan Keuangan Kementerian/Lembaga." Jurnal Akuntansi Universitas Jember 14(1):1-18.

Nasution, Anwar. 2008. "Perbaikan Pengelolaan Keuangan Negara Dalam Era Reformasi." Badan Pemeriksa Keuangan RI.

Nazier, Daeng. 2009. “Kesiapan SDM Pemerintah Menuju Tata Kelola Keuangan Negara Yang Akuntabel Dan Transparan." Seminar Nasional Badan Pemeriksa Keuangan-RI.

Nitzl, Christian, Dennis Hilgers, Bernhard Hirsch, and David Lindermüller. 2020. "The Influence of the Organizational Structure, Environment, and Resource Provision on the Use of Accrual Accounting in Municipalities." Schmalenbach 
Business Review 72(2):271-98.

Ouda, Hassan A. .. 2004. "Basic Requirements Model For Successful Implementation Of Accrual Accounting In The Public Sector." Public Fund Digest IV(1).

PP, 71 tahun 2010. 2010. "Peraturan Pemerintah No 71 Tahun 2010 Tentang Standar Akuntansi Pemerintahan." 1-30.

Putri, Novita. 2016. "Faktor-Faktor Yang Mempengaruhi Penerapan Akuntansi Pemerintah Basis Akrual Dalam Penyusunan Laporan Keuangan Pemerintah ( Studi Pada Satuan Kerja Di Lingkungan KPPN Medan II )." Universitas Sumatera Utara.

Rahmawati, Neni, Anwar Made, and Wirshandoni Doni Y. 2016. "Implementasi Standar Akuntansi Pemerintahan Berbasis Akrual Di Sekretariat DPRD Kabupaten Malang Berdasar Peraturan Pemerintah Nomor 71 Tahun 2010." Jurnal Riset Mahasiswa Akuntansi Unikama 4(1).

Robbins, Stephen. 2001. "Perilaku Organisasi: Konsep, Kontroversi, Aplikasi." Savitri, Rizky Ayu and Zaenal Fanani. 2017. "The Institutionalization of Accrual Accounting: The Perspective of New Institutional Sociology Theory." Jurnal Dinamika Akuntansi 9(2):100-109.

Scott, Wiliam R. 2003. Principal Accounting Theory. Canada: Prentice Hall.

Shawallizayusof, Nur and Hartini Jaafar. 2018. "The Implementation of AccrualBased Accounting in Malaysian Public Sector: Opportunities and Challenges." International Business Education Journal 11(1):49-62.

Sinambela, Lilian Poltak. 2018. Manajemen Sumber Daya Manusia. Jakarta: PT. Bumi Aksara.

Sopiah. 2008. Perilaku Organisasi. Yogyakarta: Andi.

Stamatiadis, Filippos and Nikolaos Eriotis. 2011. "Evolution of the Governmental Accounting Reform Implementation in Greek Public Hospitals: Testing the Institutional Framework." Joumal of Economic Policy (2116):0-33.

Sugiarto, Evan Sembada and Muhammad Alfian. 2014. "Faktor-Faktor Pendukung Atas Keberhasilan Penerapan Akuntansi Berbasis Akrual Pada Pemerintahan Di Kota Solo." Jurnal Fakultas Ekonomika Dan Bisnis Universitas Kristen Satya Wacana (November):1713-26.

Sugiyono. 2014. Metode Penelitian Kuantitatif Kualitatif Dan RED. Bandung: Alfabeta.

Sugiyono. 2017. Metode Penelitian Kuantitatif. Bandung: Alfabeta.

Supriyatno. 2010. "Pengaruh Partisipasi Pejabat Struktural Dalam Penyusunan Anggaran, Komitmen Organisasi, Profesionalisme, Dan Struktur Organisasi Pada Kinerja Manajerial Pemerintah Kota Denpasar." Universitas Udayana. Triwahyuni, Mustika, Nurazlina, and Alfiati Silfi. 2016. "Pengaruh Penerapan Standar Akuntansi Pemerintahan (SAP), Kompetensi Sumber Daya Manusia (SDM) Dan Penerapan Sistemn Akuntansi Keuangan Daerah Terhadap Kualitas Laporan Keuangan SKPD (Studi Pada Pemerintah Daerah Kota Dumai)." Jumal Online Mahasiswa Fakultas Ekonomi Universitas Riau 3(1):2312-26.

Veronica, Amelia and KA. Krisnadewi. 2009. "Pengaruh Partisipasi Penganggaran, Tekanan Anggaran, Komitmen Slack Anggaran Pada BPR Di Kabupaten Badung." 
Vertiarani, Ratu and Abdul Halim. 2019. “The Effect of Full Accrual Accounting Implementation on Audit Delay ( Evidence from Districts / Citied Government in Indonesia for The Years 2013-2016 )." THE INDONESIAN JOURNAL OF ACCOUNTING RESEARCH 22(1):91-104.

Wagner-krechlok, Kristin, Dennis Hilgers, and Helge C. Brixner. 2019. “The Introduction Of Accrual Accounting And Budgeting in The City State Of Hamburg: A Qualitative Analysis Of The Reform Process And Its Benefits." Tékhne - Review of Applied Management Studies (2018):40-51.

Wahyudi, Indra. 2019. "Analisis Kualitas Implementasi Akuntansi Berbasis Akrual." Jurnal Perbendaharaan, Keuangan Negara Dan Kebijakan Publik $4(1): 13-22$.

Wahyuni, Nina Eka and Helmy Adam. 2015. "Analisis Penerapan Standar Akuntansi Pemerintahan Berbasis Akrual Dalam Perspektif Teori Institusional: Studi Kasus Pada Pemerintah Kota Malang." Journal of Chemical Information and Modeling 53(9):1689-99.

Wibowo, dedye Priyo. 2013. “Analisis Faktor-Faktor Yang Mempengaruhi Waktu Penyelesaian Rekonsilisasi Data SAI Satuan Kerja (Studi Pada Satuan Kerja Di Wilayah Kerja KPPN Malang)."

Widianti, Hesti, Siti Nur Hadiyati, and Dewi Sulistyowati. 2016. "Analisis FaktorFaktor Yang Mempengaruhi Penerapan Akuntansi Akrual Pada Sektor Pemerintah."

Witantri, Ajeng. 2012. "Faktor-Faktor Pendukung Keberhasilan Penerapan SAP Berbasis Akrual Pada Pemerintah Kota Medan."

Yudi, Y., M. Sudarma, A. Djamhur, and Z. Baridwan. 2016. "The Meaning Behind Accrual Accounting at a Local Government in Indonesia." Russian Journal of Agricultural and Socio-Economic Sciences (RJOAS) 10(58):94-110.

Yuhelson, Dodik Ariyanto, Ernawati, Fransiska Soejono, and Sri Puspa Dewi. 2020. “Digital Economy and Financial Inclusion." Journal of Environmental Treatment Techniques 8(1):241-43. 